\title{
Bharati's Adaptation and Appropriation of French Thoughts
}

\section{Pugazhendhi Kumarasamy}

\section{$\underline{\text { Abstract }}$}

The political context, during the first half of the $20^{\text {th }}$ century, in India, prompted many Indian writers to pen against the colonial power. The aim of their literary productions was to exercise a twofold influence over the readers: heightening their awareness about freedom and also about the need for a major social reform that will serve as a foundation for the development of postindependent India. By doing so, some of the writers wrote their individual ideas while others sought to introduce, through their writings, thoughts they borrowed from their European counterparts. They translated, adapted or even appropriated these thoughts as per the requirement of the socio-political framework in which the writing and the reading took place. Subramanya Bharathi, a national poet of India, was highly influenced by French literary works during his stay in Pondicherry in 1920s. In many of his essays, he expressed the thoughts of a few French authors, not merely because he personally valued them but the need of these thoughts to intensify the freedom movement in India. This article attempts to draw attention to the relation that Subramanya Bharathi had with the French literary world.

Keywords: Subramania Bharathi, French thoughts, Indian literature, Colonial context. 


\section{Introduction:}

Chinnaswami Subramanya Bharathi is recognized as one of the most multifaceted literary figures of the 20th century India. Despite being a fervent scholar and devotee of Tamil language, he learned several other languages including French. In other words, he was exceptionally multitalented and multilingual.

His scholarly curiosity about other literatures and the world outside India made him discover, during his stay in Pondicherry, many French authors and thinkers whom he appreciated greatly. In his essays, we believe that some of his writings might have been inspired by these French personalities. We also notice that he translated some of their writings, by giving due credit to the authors. It also seems in his essays that he borrowed ideas from some French thinkers, as and when their ideas were compatible, with the message he wanted to convey to the Indian readership of his time.

The purpose of this article is twofold, first it will give an account of the French authors and thinkers whose ideas are found in Subramanya Bharathi's essays and then it will also attempt to examine the reasons for borrowing or accepting these ideas by the national poet.

\section{Bharathi's awareness about France and French}

In 1907, when Subramanya Bharathi started working as an editor for the Tamil weekly India, he also expressed his creativity and thoughts in the journal by publishing many essays, poems and songs. Most of his writings in those days were nationalistic and spiritual in nature and he published a few songs admiring the Russian and the French revolutions. In 1908, when the proprietor of the India was arrested by the British, knowing that he would also be 
arrested soon, Bharathi was compelled to leave Madras and take refuge in Pondicherry which was then a territory under the French rule.

Though he was expelled from the British India, this period of his life was the most productive in terms of writings. One of the reasons behind this may be that Bharathi's stay in Pondicherry brought him closer to many other Indian political figures such as Sri Aurobindo, as well as to the French culture, socio-political thoughts and literature. Even though the journal was banned in the British India, Bharathi continued to edit and publish the weekly journal India from Pondicherry. The new editions of the India published from Pondicherry carried the translation of French national motto in Tamil: ஸமத்துவம், சகோதரத்துவம் (swadhandhiram, samathuvam, sagodharathuvam) which means Liberty, Equality, and Fraternity in Tamil.

During his stay in Pondicherry, Bharathi learned French thoroughly with the help of a native French speaker called Antoine Arloque. He discovered slowly through books and conversations with French natives, the French culture, history and literature, and developed a keen liking for the same. He had even learnt the French national anthem by heart and used to sing it as good as a French native. Mr. R. Ganagalingam, who was made to wear the holy thread by Bharathi, mentions in his book how passionate was Bharathi about singing the French national anthem.

Bharathiyar had great love for French music. Particularly, he liked the French National Anthem, la Marseillaise, immensely. Both Bharathiyar and "pappa" Tmt. Sakunthala - learnt the French National Anthem from Antoine Arloque. 
When Bharathiyar sang la Marseillaise in solitude, he used to sing it, stamping his right foot down ferociously, and the song dripping with a martial spirit. It never occurred to those who heard him from outside that a Tamil was singing. It would appear as though, a European or a Frenchman was singing. The French pronunciation was so clear and perfect (My Revered Guru, 2006).

Bharathi was so inspired by the French national anthem that he translated the first two stanzas into Tamil with the title போர்க்கோலம் பூணுவீரே (porkolam poonuveere) which means "Let's get ready for the war" in Tamil. It's also said that he gave this translation to some school children who sang it in a play staged during a school function.

Apart from these cultural and political knowledge of France, Bharathi also constantly updated himself about the political events in France. For instance, he writes in one of his essays entitled அடங்கி நட (adangi nada) which means "be submissive", about the case of Dreyfus in France and argues that mistakes do take place even in a republic but it does not mean that we cannot rectify them. He mentions that the irregularities in the present French Republic were exposed through the case of Dreyfus but the people of France still believe that republic is the best form of government. Hence, the people of India should also believe in their ability to run the government themselves and they should not pay attention to the comments of the British who claim that Indians will commit mistakes if India is entirely handed over to them.

In addition to his cultural and political awareness about France, Bharathi was also well-read about French Literature and socio- 
political thoughts. One could come across several citations, translations, ideas of various French thinkers, and literary figures in his essays. Notably, one can find the works of Montesquieu, Voltaire, Jean Jacques Rousseau, Victor Hugo and Proudhon. In many places, Bharathi gives due credit to the author from whom he borrows the idea, and in other places one can only observe a strong resemblance between Bharathi's ideas and the writings of the French author. In such cases, we may assume that either Bharathi got inspired from the author or it's a coincidence that his ideas are similar to the ones of the French author.

\section{Montesquieu and Bharathi}

In his well-known work, The Spirit of Laws, Montesquieu holds that priests have more power amongst the barbarian people as they use superstitions to gain such power and gives the Germans the examples of his time. Bharathi in his essay, entitled யாரை தொழுவது? (yarai thozhuvadhu? which means "Whom to pray enough?") in Tamil, holds that priests use superstitions and blind beliefs to cheat common men; hence we should stop believing in their intermediary and worship God in our own way. He also says that one can get God's favor and protection just by doing good deeds. Such a person does not even need to go to a temple.

Although Bharathi's denouncement of the insincerity of priests in the beginning of the essay reflects the thought of Montesquieu, he goes further and provides a solution to the common men. In other words, Montesquieu's writing is more descriptive about the role of Priests whereas Bharathi's essay is advisory in nature. 


\section{Voltaire and Bharathi}

Voltaire in his work, Candid or the Optimism, talks about an imaginary country called "El Dorado" where gold is found abundantly and no one values gold or any material objects and only human virtues are valued, thus showing the reader the ideal world that Voltaire aspired for and therefore influencing the reader of his time to desire the same.

Similarly, Bharathi talks about an imaginary island in his short story entitled சந்திர தீவு (sandhira theevu) which literally means moon island in Tamil. In the story, the island is ruled by a king called Ganga Putiran who is in search of a groom for his daughter Chandrigai. Meanwhile, the king of Kasi in India named Vithya putiran sends his mother and his minister named Sthaman to ask for king Ganga Putiran's daughter's hand in marriage to the king of Kasi.

The King Ganga Putiran, his Minister Govinda Rajan and Sthaman go for hunting and rest under a tree and engage in a detailed, long conversation. Through this discussion which occupies most of the story, Bharathi presents his ideologies about country, kingdom, equality, women's freedom, and so on. Also, he talks about slavery referring implicitly to the colonisation in India.

Bharathi and Voltaire create an imaginary country in their stories through which they present their ideal world to the reader, thereby inspiring him or her to follow their ideology in real life. Although, the ideas are not the same between Voltaire and Bharathi, their methods of conveying the message implicitly through an imaginary space and time are common between them. 


\section{Jean Jacques Rousseau and Bharathi}

Rousseau, in his famous work, The Social Contract mentions that there are three kinds of government, namely aristocracy or monarchy, representative democracy and direct democracy and gives a detailed explanation of these governments. Bharathi, in his essay entitled ராஜ்ய சாஸ்திரம் (radjiya saasthiram) which means "Political Science" in sankritized Tamil mentions these three different kinds of governments that exist in western countries and insists that such discipline be taught to school students so that they can contribute to the political development of India.

Although the types of government mentioned in Bharathi's essay are the same as in Rousseau's work, one cannot entirely be sure of the origin as Bharathi does not give any credit to any foreign author in his essay. Moreover, Bharathi presents many other ideas in the same essay that seem to be well-suited to the Indian context, such as the development of villages and temples and houses for the poor etc.

In short, it appears that Bharathi had read Rousseau but borrowed only a few ideas and added many of his own so that it suits the Indian socio-political situation.

\section{Victor Hugo and Bharathi}

Bharathi has translated several passages from Victor Hugo's Les Misérables, giving due credit to the author. It is interesting to note that though Bharathi gave credit to the author, he does not mention the name of the literary work in his translation and he 
translated only some selected parts in which there is no trace of the storyline or of characters that are found in the novel.

Such selection implies a deliberate omission of the rest of the story to which Bharathi may not have given importance. Also, it seems that he selected these parts because they could be related to the Indian context. For example, from the novel Les Misérables he has translated a passage where social equality is discussed and he gave it the title "What is equality?". He did not translate the other ideas that are there in the same chapter of the novel. It is probably because the idea about social equality was important to the Indian context as there was casteism and other social hierarchies with which Bharathi was not happy and coincidentally he found the same idea in Victor Hugo's novel and translated it immediately.

He translated another passage from the same novel which is about love. In fact, in the novel a character called Marius writes a love letter to the women with whom he is in love. In this letter Marius gives a definition of love. Bharathi translated only this definition of love. Bharathi intentionally omitted the parts that are purely admirations and hyperboles which don't describe the real feeling of love.

We can therefore conclude that Bharathi's translation of Victor Hugo's works was motivated more socially and ideologically than literarily.

\section{Proudhon and Bharathi}

Pierre-Joseph Proudhon was the first French politician who declared himself as anarchist and who said "Property is theft". Bharathi, in one of his essays entitled செல்வம் (selvam) which 
means fortune in Tamil, quotes Proudhon and presents his antiindustrialist ideas.

Once again Bharathi seems to be motivated by the ideology of Proudhon which is pro-workers and anti-capitalistic. Bharathi further extends this ideology of Proudhon to his essay and adapts it to the Indian context; he says rich men in villages should help the poor by providing them the basic necessities such as food and shelter. He continues that we should not let the gap between the rich and the poor widen and deepen otherwise we might end-up like in Europe where there is big social discrimination between the rich and the poor.

\section{Conclusion}

In brief, one can say that Bharathi as a scholar read a lot about the French literature, the socio-political context of France and got influenced by some of the thinkers and authors. He chose to translate, adapt or appropriate, those with whom he entirely agreed and especially those relating to the problems and mind-set existed in colonized India. He might have been, as we don't have any explicit proof or open statement from the national poet himself, saying that he was inspired by some socio-political thinkers such as Voltaire, Jean Jacques Rousseau, Montesquieu and Proudhon.

\section{References:}

Bharathi, Sumbramnya. (1981). Bharathiyaar Katturaikal. Chennai, Vanathi Pathippakam.

Bharathi, Sumbramnya. (1968). Bharathiyaar Kavithaikal. Chennai, Vanathi Pathippakam. 
Hugo, Victor. (1862). Les Misérables, quatrième partie, L'idylle rue plumet et l'épopée rue Saint-Denis, Paris, J. Hetzel, Libraireéditeur.

Kanagalingam, R. (2006). My Revered guru. Mysore \& Kumbakonam: Central Institute of Indian Languages and Bharathi National Forum.

Montesquieu. (1824). De l'esprit des lois, Tome second, Paris, France, Chez Mme Veuve Dabo.

Rousseau, Jean-Jacques. (1889), Du contrat social ou principes du droit politique. Paris, France, Librairie des bibliophiles. 